Bob Herschberg has been a major source of inspiration for this Journal for almost fourteen years and this is the first issue in which he has not had a hand in the Editorial At least, his physical hand is no longer involved, but his inspirational spirit is as strong as ever In fourteen years he has scrutınized Zuse's, De Groot's and Shannon's contributions, vigorously supported young researchers and has served the computerchess community in his own inımitable way Now he has decided to retıre from the University, and from the Journal

I would like to thank my source of inspiration, in verba magistrl, by quotıng Jonathan Swift

"Then, rising with Aurora's light,

The Muse involved, sit down to write,

Blot out, correct, insert, refine,

Enlarge, dımınısh, interlıne "

Jaap van den Herık

\title{
BOB MAY BE MISSED, BUT HARDLY FORGOTTEN!
}

For nearly two decades the ICCA has kept in touch with its members through the Journal, and its predecessor the Newsletter Since 1983 the Journal itself, under the stewardship of its Editor-in-Chief (Jaap van den Herık), has gone from strength to strength Not so well-known, perhaps, is that the excellent work done by the editorial office has been strongly supported by the European Editor, I S "Bob" Herschberg

Bob, formerly a Professor of Computer Science at the Delft Unıversity of Technology, has outstanding credentials for assessing the scientific contributions of the Journal's authors Not an article has gone by without a careful reading by Bob, not an editorial was written without his guiding hand But all good things come to an end, and it is now with dismay that the Executıve Board realızes that Bob really is retıring from his editorial role Those of us who are part of the computer revolution are too young to retire, and yet it is somethıng that we should all look forward to one day

It will be impossible to replace Bob's role as "Chief Assistant to the Editor-in-Chief", though sometımes authors wondered who was the assistant and who the chief' Bob's command of the language, his multılıngual abılities and his breadth of experience and educatıon made hım a delightful colleague His well-established insights into computer chess, and his general knowledge and methodical approach to serious writıng made hım a near perfect editor This gave hım great confidence and courage when correctıng grammatıcal errors, ınsertıng "better" words and callıng to account even those who genuınely belıeved theır English to be above reproach He was generally right, though his choice of words sometımes seemed obscure or alien (almost too perfect') His gift for seeing all the possible interpretations of the text, and his mastery of the double entendre, often put him on the borderlıne between perfection and pedantry when proposing changes While there is no hope that we can find another volunteer to follow his footsteps precisely, we will begin immediately to find a replacement who is at least as diligent and conscientious

Bob will be sorely missed, but how will he fill his day, I wonder? Perhaps we can twist an arm here, provide some pressure there, and convince Bob to return from tıme to tıme as Guest Editor for selected issues Maybe even once a year Bob could write an independent editorial review of an issue, or write the occasional letter to the editor with a position statement or a clarification to some author's potentially ambiguous text Bob will be missed, but not forgotten The executive board, on behalf of all readers, wish Bob many, many years of retırement and look forward to his (electronic or otherwise) correspondences from Delft 